\title{
DOCA Sensitive Pendrin Expression in Kidney, Heart, Lung and Thyroid Tissues
}

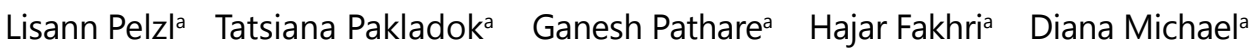 \\ Carsten A. Wagner ${ }^{b}$ Markus Paulmichlc Florian Lang ${ }^{\mathrm{a}}$ \\ aDepartment of Physiology, University of Tuebingen; 'Institute of Physiology and Zurich Center for \\ Integrative Human Physiology (ZIHP), University of Zurich; 'Institute of Pharmacology and Toxicology, \\ Paracelsus Medical University, Salzburg
}

\author{
Key Words \\ Slc26a4 • Acidosis • Alkalosis • Liver • Kidney
}

\begin{abstract}
Background/Aims: Pendrin (SLC26A4), a transporter accomplishing anion exchange, is expressed in inner ear, thyroid gland, kidneys, lung, liver and heart. Loss or reduction of function mutations of SLC26A4 underlie Pendred syndrome, a disorder invariably leading to hearing loss with enlarged vestibular aqueducts and in some patients to hypothyroidism and goiter. Renal pendrin expression is up-regulated by mineralocorticoids such as aldosterone or deoxycorticosterone (DOCA). Little is known about the impact of mineralocorticoids on pendrin expression in extrarenal tissues. Methods: The present study utilized RT-qPCR and Western blotting to quantify the transcript levels and protein abundance of Slc26a4 in murine kidney, thyroid, heart and lung prior to and following subcutaneous administration of 100 mg/kg DOCA. Results: Slc26a4 transcript levels as compared to Gapdh transcript levels were significantly increased by DOCA treatment in kidney, heart, lung and thyroid. Accordingly pendrin protein expression was again significantly increased by DOCA treatment in kidney, heart, lung and thyroid. Conclusion: The observations reveal mineralocorticoid sensitivity of pendrin expression in kidney, heart, thyroid and lung.
\end{abstract}

Copyright $(2012$ S. Karger AG, Basel

\section{Introduction}

Pendrin is an electroneutral anion exchanger transporting chloride, bicarbonate, iodide and further anions [1-3]. Loss or reduction of function mutations in the pendrin gene 
(SLC26A4) [4-9] lead to autosomal-recessive Pendred syndrome (PDS) with sensorineural hearing loss paralleled by enlarged vestibular aqueducts $[3,10,11]$. Lack of functional pendrin may further result in an iodide organification defect with an enhanced risk of developing goiter and hypothyroidism $[3,12,13]$. The development of goiter and hypothyroidism in Pendred syndrome is variable and may depend on nutritional iodide intake $[13,14]$.

SLC26A4 is expressed in a variety of tissues including thyroid gland, inner ear, kidney, lung, liver and heart [12, 14-17]. SLC26A4 mediated transport is critically important for proper development of the inner ear $[18,19]$. The precise contribution of SLC26A4 to iodide transport in thyroid glands has, however, been a matter of debate [12, 14, 20, 21]. SLC26A4 contributes to cell volume regulation [22], airway transport regulation [23, 24] as well as $\mathrm{HCO}_{3}^{-}$secretion and $\mathrm{Cl}^{-}$reabsorption in the distal nephron [17, 25-28]. Renal tubular SLC26A4 influences expression and activity of the epithelial $\mathrm{Na}^{+}$channel $\mathrm{ENaC}$ and therefore impacts on blood pressure regulation [28-33].

SLC26A4 expression and function is up-regulated by ambient $\mathrm{pH}$, aldosterone, intestinal natriuretic hormone, angiotensin II and the pro-inflammatory cytokines, interleukin (IL)-4 and IL-13. [28, 30, 34-39].

Mineralocorticoid sensitivity of renal SLC26A4 expression is well established [28, 30, 32]. Mineralocorticoid receptors are, however, expressed in a wide variety of further tissues [40], including colon, lung, cardiac myocytes, blood vessels, hippocampus, adipose tissue and thyroids [41-46]. Mineralocorticoids play a decisive role in a wide variety of functions, such as renal and colonic $\mathrm{Na}^{+}$and $\mathrm{K}^{+}$transport [45], salt appetite [47], hypertension [48], cardiac remodelling and fibrosis [49-52], stiff endothelial cell syndrome (SECS) [53-56], vascular stiffness [57] and calcification [58, 59], as well as apoptosis in hippocampal neurons [60]. Accordingly, aldosterone influences the expression of a wide variety of genes related to those functions [58, 61-66].

Little is known about the effect of aldosterone on SLC26A4 expression in tissues other than kidney, such as heart, lung and thyroid gland. The present study thus explored the effect of the mineralocorticoid deoxycorticosterone (DOCA) on the transcript levels and protein abundance of Slc26a4 in murine kidney, cardiac, lung and thyroid tissues.

\section{Materials and Methods}

\section{Animals}

Experiments were performed in 8-10 week old female and male wild type mice. All animal experiments were conducted according to German and Swiss laws for the welfare of animals and were approved by local authorities. The animals had free access to food (C1310, Altromin, Heidenau, Germany) and tap water. Where indicated the animals were treated with subcutaneous injections of deoxycorticosterone (DOCA, Sigma, Taufkirchen, Germany) 3 hours prior to determination of Slc26a4 transcript and protein levels.

\section{RT-PCR analysis}

To determine Slc26a4 mRNA abundance in mouse organs total RNA was extracted from both tissues using Trifast Reagent (Peqlab, Erlangen, Germany) according to the manufacturer's instructions. Reverse transcription of $2 \mu \mathrm{g}$ RNA was performed using oligo(dT) ${ }_{12-18}$ primers (Invitrogen, Karlsruhe, Germany) and SuperScript III Reverse Transcriptase (Invitrogen, Karlsruhe, Germany). cDNA samples were treated with RNase H (Invitrogen, Karlsruhe, Germany). Quantitative RT-PCR was performed with theiCycleriQ ${ }^{\mathrm{TM}}$ Real-Time PCR Detection System (Bio-Rad Laboratories, Hercules, CA) and iTaq ${ }^{\text {TM }}$ Sybr Green Supermix with ROX (BioRad Laboratories, Hercules, CA) according to the manufacturer's instructions. The following primers were used (5' $\rightarrow 3^{\prime}$ orientation): Slc26a4 s: TTCGGTCTCTACTCTGCCTTT; Slc26a4 as: CCCACCATTAAACTGACCACG; Gapdh s: AGGTCGGTGTGAACGGATTTG; Gapdh as: TGTAGACCATGTAGTTGAGGTCA. The specificity of the PCR products was confirmed by analysis of the melting curves and in addition by agarose gel electrophoresis. All PCRs were performed in duplicate, and mRNA fold changes were calculated by the $68^{\circ} \mathrm{C}$ method using Gapdh as an internal reference. 


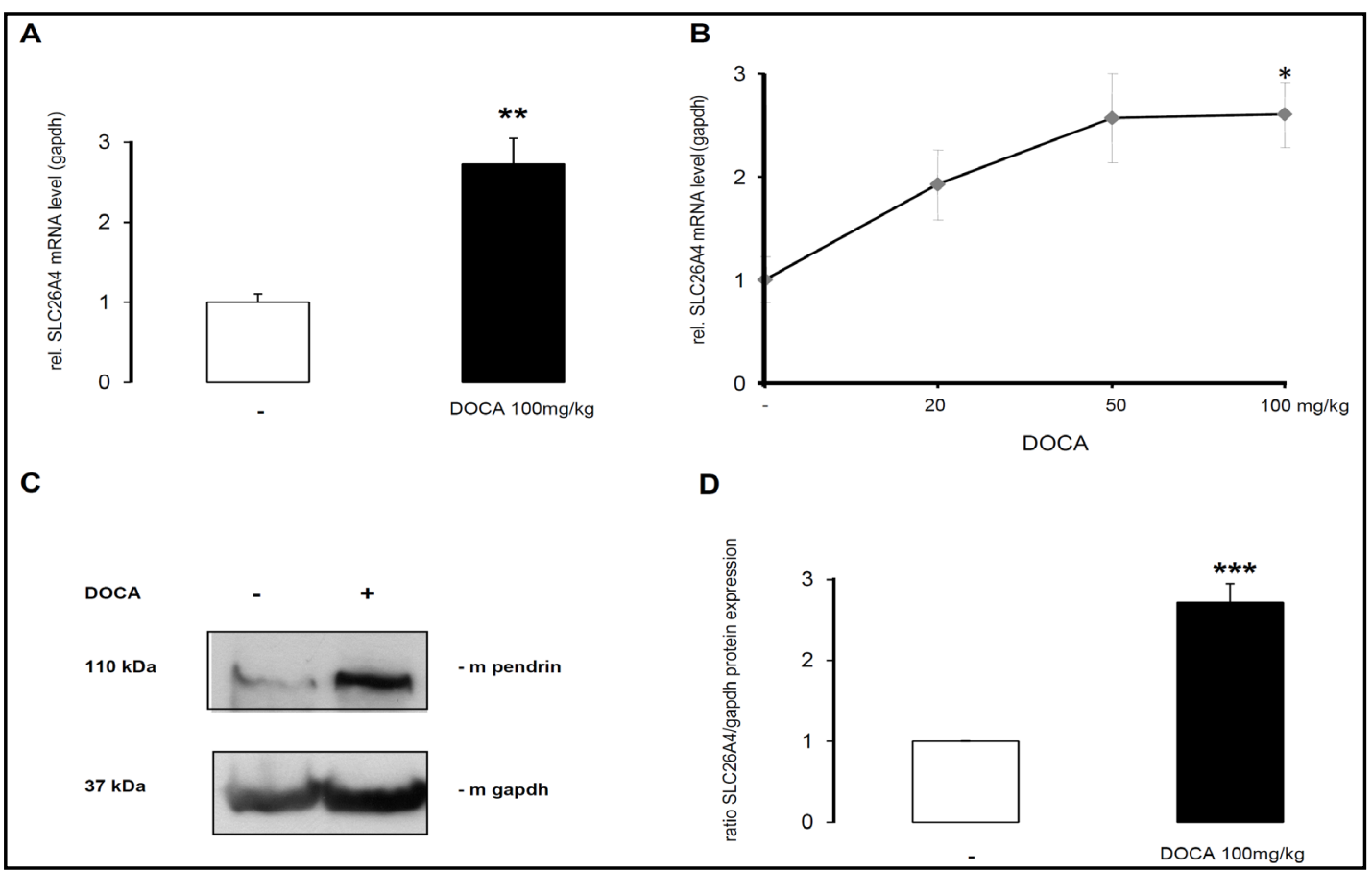

Fig. 1. Slc26a4 mRNA and protein abundance in kidney without and with DOCA treatment. A. Arithmetic means \pm SEM $(n=5)$ of Slc26a4 mRNA abundance in kidney from animals without treatment (white bar) and 3 hours following subcutaneous injection of $100 \mathrm{mg} / \mathrm{kg}$ DOCA (black bar). ${ }^{* *}(\mathrm{p}<0.01)$ indicates statistically significant difference with respect to untreated animals. B. Dose response curve of DOCA induced up-regulation of Slc26a 4 mRNA levels. ${ }^{*}(\mathrm{p}<0.05)$ indicates statistically significant difference to untreated animals. C. Representative original blot for pendrin protein abundance in kidney from animals without treatment (-DOCA) and 3 hours following subcutaneous injection of $100 \mathrm{mg} / \mathrm{kg}$ DOCA (+DOCA). D. Arithmetic means \pm SEM $(n=5)$ of Slc $26 a 4$ protein abundance in kidney from animals without treatment (white bar) and 3 hours following subcutaneous injection of $100 \mathrm{mg} / \mathrm{kg}$ DOCA (black bar). ${ }^{* * *}(\mathrm{p}<0.001)$ indicates statistically significant difference to untreated animals.

\section{Membrane preparation and western blot analysis}

For determination of Slc26a4 protein abundance, tissue samples were homogenized in an ice-cold K-HEPES buffer (200 mM mannitol, $80 \mathrm{mM}$ HEPES, $41 \mathrm{mM} \mathrm{KOH,} \mathrm{pH} \mathrm{7.5)} \mathrm{containing} \mathrm{a} \mathrm{protease} \mathrm{inhibitor}$ mix (Complete Mini, Roche Diagnostics, Germany; 1 tablet in a volume of $10 \mathrm{ml}$ ). Samples were centrifuged at $1500 \mathrm{xg}$ for $10 \mathrm{~min}$ at $4^{\circ} \mathrm{C}$. Subsequently, the supernatant was transferred to a new tube and centrifuged at $12000 \mathrm{xg}$ for $1 \mathrm{~h}$ at $4^{\circ} \mathrm{C}$. The resultant pellet was resuspended in K-HEPES buffer containing protease inhibitors. After measurement of the total protein concentration (Bio-Rad D Protein Assay; Bio-Rad, Hercules, CA, USA), $100 \mu \mathrm{g}$ of crude membrane proteins were solubilized in Laemmli sample buffer, and SDS-PAGE was performed on 8\% polyacrylamide gels. For immunoblotting, proteins were transferred electrophoretically to polyvinylidene difluoride membranes (Immobilon-P; Millipore, Bedford, MA, USA). After blocking with 5\% milk powder in Tris-buffered saline/0.1\% Tween-20 for 60 min, the blots were incubated with the respective primary antibodies (rabbit anti-pendrin 1:1000 [67] and rabbit monoclonal anti-gapdh antibody (37 kDa; Cell Signaling Technology) 1:2000, diluted in 1\% milk/TBS-T) either for $2 \mathrm{~h}$ at room temperature or overnight at $4^{\circ} \mathrm{C}$. After washing and subsequent blocking, the membranes were incubated for $1 \mathrm{~h}$ at room temperature with the secondary antibody conjugated with horse radish peroxidase (HRP) (1:2000, Cell Signaling). After washing antibody binding was detected with the ECL detection reagent (Amersham). All Bands were analyzed with Quantity One Software (Biorad).

\section{Statistical analysis}

As indicated, data are provided as means \pm SEM; $n$ represents the number of independent experiments. All data were tested for significance using Student's unpaired two-tailed t-test where applicable. Only differences with $p<0.05$ were considered statistically significant. 


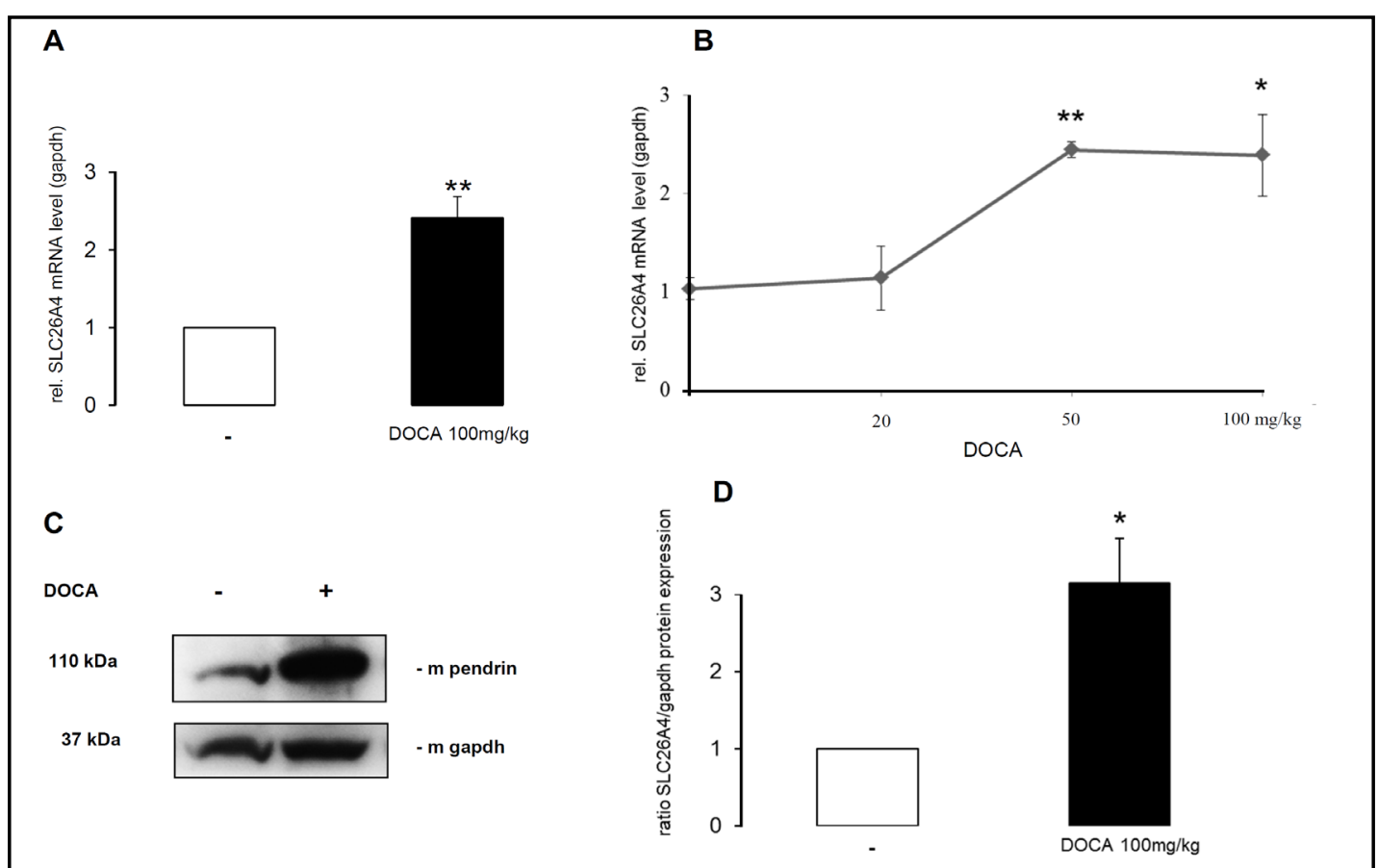

Fig. 2. Slc26a4 mRNA and protein abundance in heart without and with DOCA treatment. A. Arithmetic means \pm SEM $(n=9)$ of Slc26a4 mRNA abundance in heart from animals without treatment (white bar) and 3 hours following subcutaneous injection of $100 \mathrm{mg} / \mathrm{kg}$ DOCA (black bar). ${ }^{* *}(\mathrm{p}<0.01)$ indicates statistically significant difference to untreated animals. B. Dose response curve of DOCA induced up-regulation of Slc26a4 mRNA levels. ${ }^{*}(\mathrm{p}<0.05),{ }^{* *}(\mathrm{p}<0.01)$ indicates statistically significant difference to untreated animals. C. Representative original blot for pendrin protein abundance in heart from animals without treatment (-DOCA) and 3 hours following subcutaneous injection of $100 \mathrm{mg} / \mathrm{kg}$ DOCA (+DOCA). D. Arithmetic means \pm SEM $(n=5)$ of SLC26A4 protein abundance in heart from animals without treatment (white bar) and 3 hours following subcutaneous injection of $100 \mathrm{mg} / \mathrm{kg}$ DOCA (black bar). $*(\mathrm{p}<0.05)$ indicates statistically significant difference to untreated animals.

\section{Results}

Semi-quantitative reverse transcription polymerase chain reaction (RT-qPCR) was employed to quantify the transcript levels encoding Slc26a4 and Western blotting was utilized to quantify the Slc26a4 protein abundance in murine kidney, thyroid, heart and lung prior to and following subcutaneous administration of 20,50 or $100 \mathrm{mg} / \mathrm{kg}$ DOCA.

As illustrated in Fig. 1A,B, the abundance of Slc26a4 mRNA in the kidney was significantly increased following treatment of mice with the deoxycorticosterone DOCA $(100 \mathrm{mg} / \mathrm{kg})$. Normalization of the Slc26a4 transcript levels to the transcript levels of the house keeping gene Gapdh yielded the Slc26a4/Gapdh transcript level ratio, which was significantly increased by DOCA treatment (by 160\%, $\mathrm{n}=5$ ). The increase of Slc26a4 transcript levels following DOCA treatment was paralleled by an increase of Slc26a4 protein abundance (Fig. $1 \mathrm{C}$ and Fig. 1D).

Similar to what was observed in the kidney, DOCA (50 or $100 \mathrm{mg} / \mathrm{kg}$ ) treatment significantly increased Slc26a4 transcript levels in the heart (Fig. 2A,B). The increase of the cardiac Slc26a4 transcript levels following DOCA treatment was similarly evidenced by an increase of the Slc26a4/Gapdh transcript level ratio in the heart (by $160 \%, n=9$ ). The increase of cardiac Slc26a4 transcript levels following DOCA treatment was similarly paralleled by an increase of cardiac SLC26A4 protein abundance (Fig. 2C and Fig. 2D).

As illustrated in Fig. 3A,B, both, Slc26a4 mRNA and protein were expressed in the lung. Similar to what was observed in kidney and heart, the mineralocorticoid treatment (DOCA 50 or $100 \mathrm{mg} / \mathrm{kg}$ ) significantly increased lung Slc26a4 transcript levels. The increase of 


\section{A}
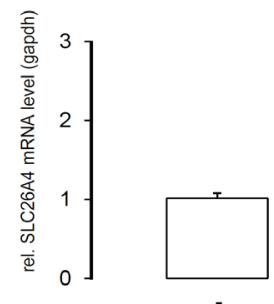

C

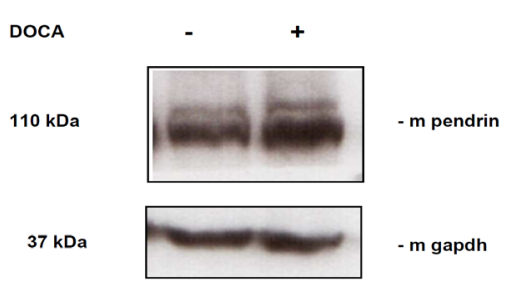

$\mathbf{B}$
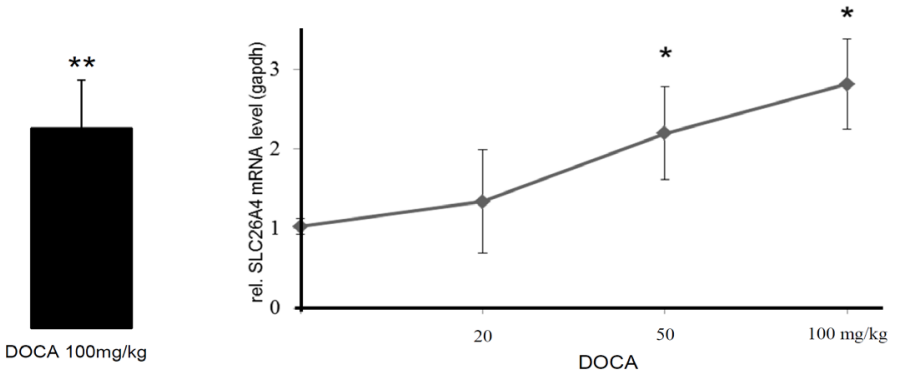

D

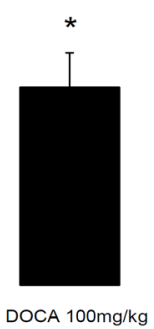

Fig. 3. SLC26A4 mRNA and protein abundance in lung without and with DOCA treatment. A. Arithmetic means \pm SEM ( $n=9$ ) of Slc26a4 mRNA abundance in lung from animals without treatment (white bar) and 3 hours following subcutaneous injection of $100 \mathrm{mg} / \mathrm{kg}$ DOCA (black bar). ${ }^{* *}(\mathrm{p}<0.01)$ indicates statistically significant difference to untreated animals. B. Dose response curve of DOCA induced up-regulation of Slc26a4 mRNA levels. ${ }^{*}(\mathrm{p}<0.05)$ indicates a statistically significant difference to untreated animals. C. Representative original blot for pendrin protein abundance in lung from animals without treatment (-DOCA) and 3 hours following subcutaneous injection of $100 \mathrm{mg} / \mathrm{kg}$ DOCA (+DOCA). D. Arithmetic means \pm SEM ( $\mathrm{n}=6)$ of SLC26A4 protein abundance in lung from animals without treatment (white bar) and 3 hours following subcutaneous injection of $100 \mathrm{mg} / \mathrm{kg}$ DOCA (black bar). ${ }^{*}(\mathrm{p}<0.05)$ indicates statistically significant difference to untreated animals.

Slc26a4 transcript levels following DOCA treatment was again evidenced by an increase of Slc26a4/Gapdh transcript level ratio (by $153 \%, \mathrm{n}=9$ ). The increase of Slc26a4 transcript levels following DOCA treatment was again paralleled by an increase of Slc26a4 protein abundance (Fig. 3C and Fig. 3D).

Lastly, DOCA (50 or $100 \mathrm{mg} / \mathrm{kg}$ ) treatment increased Slc26a4 transcript levels in thyroid gland (Fig. 4A,B). The increase of the thyroid Slc26a4 transcript levels following DOCA treatment was again evidenced by an increase of the Slc26a4/Gapdh transcript level ratio (by $319 \%, n=7$ ). The increase of thyroid Slc26a4 transcript levels following DOCA treatment was again paralleled by an increase of thyroid Slc26a4 protein abundance (Fig. 4C and Fig. 4D).

\section{Discussion}

The present study demonstrates that pendrin transcript (Slc26a4) levels and pendrin protein abundance in kidney, heart, lung and thyroids are modified by the mineralocorticoid deoxycorticosterone (DOCA).

The present study did not attempt to define the molecular mechanisms involved in the up-regulation of the carrier. A candidate signaling molecule is the serum \& glucocorticoid inducible kinase SGK1, which is strongly upregulated by mineralocorticoids and is a powerful regulator of a variety of channels and transporters [68]. SGK1 is partially effective by upregulating the transcription factor $\mathrm{NFKB}$ [69], which contributes to the stimulating effect of 
A
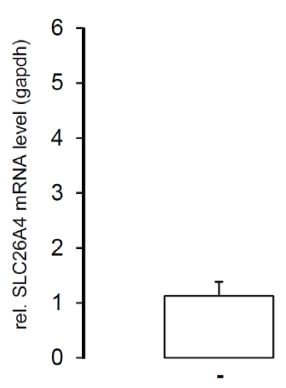

C

DOCA

$110 \mathrm{kDa}$

$37 \mathrm{kDa}$
DOCA $100 \mathrm{mg} / \mathrm{kg}$

- m pendrin

- m gapdh

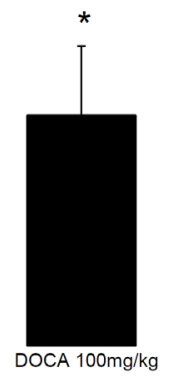

B

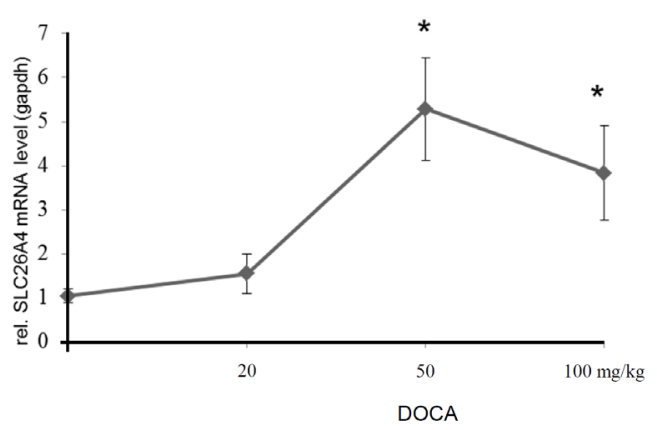

D

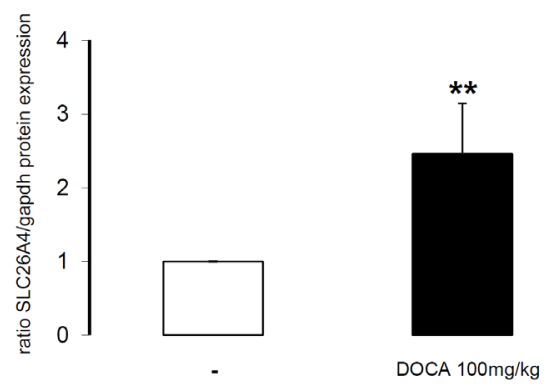

Fig. 4. SLC26A4 mRNA and protein abundance in thyroid gland without and with DOCA treatment. A. Arithmetic means \pm SEM $(n=7)$ of Slc26a4 mRNA abundance in thyroid gland from animals without treatment (white bar) and 3 hours following subcutaneous injection of $100 \mathrm{mg} / \mathrm{kg}$ DOCA (black bar). $*(p<0.05)$ indicates statistically significant difference to untreated animals. B. Dose response curve of DOCA induced up-regulation of Slc26a4 mRNA levels. ${ }^{*}(\mathrm{p}<0.05)$ indicates statistically significant difference to untreated animals. C. Representative original blot for pendrin protein abundance in thyroid gland from animals without treatment (-DOCA) and 3 hours following subcutaneous injection of $100 \mathrm{mg} / \mathrm{kg}$ DOCA (+DOCA). D. Arithmetic means \pm SEM $(n=5)$ of SLC26A4 protein abundance in thyroid gland from animals without treatment (white bar) and 3 hours following subcutaneous injection of $100 \mathrm{mg} / \mathrm{kg}$ DOCA (black bar). $* *(\mathrm{p}<0.01)$ indicates statistically significant difference to untreated animals.

mineralocorticoids on inflammation and fibrosis [70]. Whether or not NFKB is involved in the up-regulation of SLC26A4 expression during mineralocorticoid excess or inflammation, remains to be tested.

The effect of DOCA on SLC26A4 expression in the kidney is expected to affect $\mathrm{HCO}_{3}$ secretion and $\mathrm{Cl}^{-}$reabsorption across the distal nephron [17, 25-28]. Moreover, SLC26A4 is expected to modify expression and function of the renal epithelial $\mathrm{Na}^{+}$channel $\mathrm{ENaC}$ resulting in enhanced renal tubular $\mathrm{NaCl}$ transport and increased blood pressure [28-33]. As a matter of fact, pendrin deficient mice are resistant to aldosterone-induced hypertension [32].

The up-regulation of SLC26A4 expression in lung tissue may serve to foster transport of anions across the aiway epithelium $[23,24]$. Notably, SLC26A4 expression is up-regulated in bronchial asthma and chronic obstructive pulmonary disease. The carrier presumably does play an active role in respiratory inflammation and tissue destruction/remodeling [23, 24].

The effect of DOCA treatment on SLC26A4 protein abundance is only moderate in lung tissue. Nevertheless, the effect is statistically significant. Possibly, mineralocorticoids upregulate SLC26A4 protein abundance only in a subset of cells in lung tissue. If so, Western blotting of whole organ tissue would underestimate the effect on mineralocorticoid sensitive cells.

The functional role of pendrin sensitivity to DOCA in other tissues is less obvious. In theory, the up-regulation of pendrin in the thyroid could impact on the formation of thyroid 
hormones. Loss of function SLC26A4 mutations, however, do not necessarily affect iodide transport and hormone release in thyroid glands [12,14, 20,21]. Thus, aldosterone sensitive regulation of SLC26A4 in the thyroid may be relevant for functions other than thyroid hormone release. It is worth mentioning, however, that the heart has been claimed to possess all enzymes required for thyroid hormone formation [16].

SLC26A4 is further known to serve cell volume regulation [22]. Parallel activation of $\mathrm{Na}^{+} / \mathrm{H}^{+}$exchangers and $\mathrm{Cl}^{-} / \mathrm{HCO}_{3}{ }^{-}$exchangers participate in cell volume increase $[71,72]$, as they accomplish cellular $\mathrm{NaCl}$ uptake, which in turn is followed by osmotically driven water entry. Extrusion of $\mathrm{H}^{+}$by $\mathrm{Na}^{+} / \mathrm{H}^{+}$exchange and extrusion of $\mathrm{HCO}_{3}^{-}$by $\mathrm{Cl}^{-} / \mathrm{HCO}_{3}^{-}$exchange, respectively, are osmotically not relevant, as $\mathrm{H}^{+}$and $\mathrm{HCO}_{3}^{-}$are replenished in the cell from $\mathrm{CO}_{2}$ via $\mathrm{H}_{2} \mathrm{CO}_{3}[10$, 71]. Along those lines, aldosterone is known to upregulate $\mathrm{Na}^{+} / \mathrm{H}^{+}$exchange in the kidney [7380], heart [81-85], and a variety of other extrarenal tissues [86-103].

Opposite regulation of SLC26A4 activity and expression have previously been observed in liver and kidney following alterations of acid base balance [15]. Following acidosis Slc26a4 transcript levels, protein abundance and/or activity are down-regulated in kidney [15, 27, 67, 104] and Slc26a4 transcript levels are up-regulated in liver [15]. Similarly, carbonic anhydrase inhibition or deficiency downregulate Slc26a4 expression in the kidney [15, $105,106]$ but up-regulate Slc26a4 transcript levels in liver [15]. Conversely, bicarbonate induced metabolic alkalosis up-regulates Slc26a4 expression in the kidney [15, 105], but down-regulates Slc26a4 transcript levels in liver [15]. The opposite regulation of pendrin in liver and kidney may serve the complimentary functions of these organs in the regulation of systemic acid-base balance [107]. As mineralocorticoids stimulate renal tubular $\mathrm{H}^{+}$secretion and thus cause alkalosis [27], their effect on renal pendrin may similarly aim to influence acid base balance.

In conclusion, Slc26a4 transcripts and protein were observed in kidney, thyroids, lung and heart. Moreover, SLC26A4 abundance was sensitive to DOCA not only in kidney, but as well in heart, thyroids and lung. The present observation point to DOCA sensitive pendrin functions beyond its well established role in inner ear, thyroids and kidney.

\section{Acknowledgements}

This study has been supported by the Deutsche Forschungsgemeinschaft to F. Lang and the $7^{\text {th }}$ EU Program EUNEFRON to C.A. Wagner. This work was further supported by the FWF and the FP-7 to M.P. (P18608; PIRSES-GA-2008-230661).

\section{References}

1 Dossena S, Nofziger C, Lang F, Valenti G, Paulmichl M: THE ESF Meeting on "The Proteomics, Epigenetics, and Pharmacogenetics of Pendrin". Cell Physiol Biochem 2011;28:377-384.

-2 Reimold FR, Heneghan JF, Steward AK, Zelikovic I, Vandorpe DH, Shmukler BE, Alper SL: Pendrin function and regulation in Xenopus oocytes. Cell Physiol Biochem 2011;28:435-450.

-3 Choi BY, Muskett J, King KA, Zalewski CK, Shawker T, Reynolds JC, Butman JA, Brewer CC, Stewart AK, Alper SL, Griffith AJ: Hereditary hearing loss with thyroid abnormalities. Adv Otorhinolaryngol 2011;70:43-49.

4 Bizhanova A, Chew TL, Khuon S, Kopp P: Analysis of cellular localization and function of carboxy-terminal truncations mutants of pendrin. Cell Physiol Biochem 2011;28:423-434.

5 Dossena S, Nofziger C, Brownstein ZN, Kanaan M., Avraham KB, Paulmichl M: Functional characterization of Pendrin mutations found in Israeli and Palestinian populations. Cell Physiol Biochem 2011;28:477-484.

6 Dossena S, Bizhanova A, Nofziger C, Bernardinelli E, Ramsauer J, Kopp P, Paulmichl M: Identification of allelic variants of pendrin (SLC26A4) with loss and gain of function. Cell Physiol Biochem 2011;28:467-476. 
7 Dossena S, Nofziger C, Tamma G, Bernardinelli E, Vanoni S, Nowak C, Grabmayer E, Koessler S, Stephan S, Patsch W, Paulmichl M: Molecular and functional characterization of human pendrin and its allelic variants. Cell Physiol Biochem 2011;28:451-466.

-8 Sharma AK, Rigby AC, Alper SL: STAS domain structure and function. Cell Physiol Biochem 2011;28:407-422.

-9 Dossena S, Rodighiero S, Vezzoli V, Nofziger C, Salvioni E, Boccazzi M, Grabmayer E, Botta G, Meyer G, Fugazzola L, Beck-Peccoz P, Paulmichl M: Functional characterization of wild-type and mutated pendrin (SLC26A4), the anion transporter involved in Pendred syndrome. J Mol Endocrinol 2009;43:93-103.

10 Lang F, Foller M, Lang K, Lang P, Ritter M, Vereninov A, Szabo I, Huber SM, Gulbins E: Cell volume regulatory ion channels in cell proliferation and cell death. Methods Enzymol 2007;428:209-225.

11 Maciaszczyk K, Lewinski A: Phenotypes of SLC26A4 gene mutations: Pendred syndrome and hypoacusis with enlarged vestibular aqueduct. Neuro Endocrinol Lett 2008;29:29-36.

12 Bizhanova A, Kopp P: Minireview: The sodium-iodide symporter NIS and pendrin in iodide homeostasis of the thyroid. Endocrinology 2009;150:1084-1090.

13 Calebiro D, Porazzi P, Bonomi M, Lisi S, Grindati A, De Nittis D, Fugazzola L, Marino M, Botta G, Persani L: Absence of primary hypothyroidism and goiter in Slc26a4 (-/-) Mice Fed on a Low Iodine Diet. J Endocrinol Invest 2011;34:593-598.

14 Bizhanova A, Kopp P: Genetics and phenomics of Pendred syndrome. Mol Cell Endocrinol 2010;322:83-90.

15 Alesutan I, Daryadel.A., Mohebbi N, Pelzl L, Leibrock C, Voelkl J, Bourgeois S, Dossena S, Nofziger C, Paulmichl M, Wagner CA, Lang F: Impact of bicarbonate, ammonium chloride and acetazolamide on hepatic and renal Slc26A4 expression. Cell Physiol Biochem 2011;28:553-558.

16 Meischl C, Buermans HP, Hazes T, Zuidwijk MJ, Musters RJ, Boer C, van Lingen A, Simonides WS, Blankenstein MA, Dupuy C, Paulus WJ, Hack CE, Ris-Stalpers C, Roos D, Niessen HW: H9c2 cardiomyoblasts produce thyroid hormone. Am J Physiol Cell Physiol 2008;294:C1227-C1233.

17 Wagner CA, Mohebbi N, Capasso G, Geibel JP: The anion exchange pendrin (SLC26A4) and renal-acid-base homeostasis. Cell Physiol Biochem 2011;28:497-504.

18 Dror AA, Brownstein ZN, Avraham KB: Integration of Human and Mouse Genetics Reveals Pendrin Function in Hearing and Deafness. Cell Physiol Biochem 2011;28:535-544.

19 Ito T, Choi BY, King KA, Zalewski CK, Muskett J, Chattaraj P, Shawker T, Reynolds JC, Butman JA, Brewer CC, Wangemann P, Alper SL: SLC26A4 genotypes and phenotypes associated with enlargement of the vestibular aqueduct. Cell Physiol Biochem 2011;28:545-552.

20 Bizhanova A, Kopp P: Controversies concerning the role of pendrin as apical iodide transporter in thyroid follicular cells. Cell Physiol Biochem 2011;28:485-490.

-21 Twyffels L, Massart C, Golstein PE, Raspe E, Van Sande J, Dumont JE, Beauwens R, Kruys V: Pendrin: the thyrocyte apical membrane iodide transporter? Cell Physiol Biochem 2011;28:491-496.

22 Rodighiero S, Botta G, Bazzini C, Meyer G: Pendrin overexpression affects cell volume recovery, intracellular $\mathrm{pH}$ and chloride concentration after hypotonicity-induced cell sweeling. Cell Physiol Biochem 2011;28:559-570.

23 Izuhara K, Ohta S, Shiraishi H, Suzuki S, Taniguchi K, Toda S, Tanabe T, Yasuo M, Kubo K, Hoshino T, Aizawa H: The mechanism of mucus production in bronchial asthma. Curr Med Chem 2009;16:2867-2875.

24 Nofziger C, Dossena S, Suzuki S, Izuhara K, Paulmichl M: Pendrin function in Airway Epithelia. Cell Physiol Biochem 2011;28:571-578.

25 Carraro-Lacroix LR, Malnic G: Acid-base transport by the renal distal nephron. J Nephrol 2010;23:S19-S27.

-26 Sindic A, Schlatter E: Renal electrolyte effects of guanylin and uroguanylin. Curr Opin Nephrol Hypertens 2007;16:10-15.

27 Wagner CA, Devuyst O, Bourgeois S, Mohebbi N: Regulated acid-base transport in the collecting duct. Pflugers Arch 2009;458:137-156.

28 Wall SM, Pech V: Pendrin and sodium channels: relevance to hypertension. J Nephrol 2010;23 Suppl 16:S118-S123.

29 Amlal H, Soleimani M: Pendrin as a novel target for diuretic therapy. Cell Physiol Biochem 2011;28:521-526.

30 Eladari D, Chambrey R, Frische S, Vallet M, Edwards A: Pendrin as a regulator of ECF and blood pressure. Curr Opin Nephrol Hypertens 2009;18:356-362.

-31 Hadchouel J, Buesst C, Procino G, Valenti G, Chambrey R, Eladari D: Regulation of the extracellular fluid volume and blood pressure by pendrin. Cell Physiol Biochem 2011;28:505-512.

-32 Verlander JW, Hassell KA, Royaux IE, Glapion DM, Wang ME, Everett LA, Green ED, Wall SM: Deoxycorticosterone upregulates PDS (Slc26a4) in mouse kidney: role of pendrin in mineralocorticoid-induced hypertension. Hypertension 2003;42:356-362.

33 Wall SM, Kim YH, Stanley L, Glapion DM, Everett LA, Green ED, Verlander JW: NaCl restriction upregulates renal Slc26a4 through subcellular redistribution: role in Cl- conservation. Hypertension 2004;44:982-987. 
-34 Nofziger C, Vezzoli V, Dossena S, Schonherr T, Studnicka J, Nofziger J, Vanoni S, Stephan S, Silva ME, Meyer G, Paulmichl M: STAT6 links IL-4/IL-13 stimulation with pendrin expression in asthma and chronic obstructive pulmonary disease. Clin Pharmacol Ther 2011;90:399-405.

-35 Wagner CA, Mohebbi N, Uhlig U, Giebisch GH, Breton S, Brown D, Geibel JP: Angiotensin II stimulates H+-ATPase activitiy in intercalated cells from isolated mouse connecting tubules and cortical collecting ducts. Cell Physiol Biochem 2011;28:513-520.

-36 Adler L, Efrati E, Zelikovic I: Molecular mechanisms of epithelial cell-specific expression and regulation of the human anion exchanger (pendrin) gene. Am J Physiol Cell Physiol 2008;294:C1261-C1276.

37 Lee A, Nofziger C, Dossena S, Vanoni S, Diasio R, Paulmichl M: Methylation of the Human Pendrin Promoter. Cell Physiol Biochem 2011;28:394-406.

-38 Rozenfeld J, Efrati E, Adler L, Tal O, Carrithers S, Alper SL, Zelikovic I: Transcriptional Regulation of the Pendrin Gene. Cell Physiol Biochem 2011;28:385-396.

-39 Verlander JW, Hong S, Pech V, Bailey JL, Agazatian D, Matthews SW, Coffman TM, Le T, Inagami T, Whitehill FM, Weiner ID, Farley DB, Kim YH, Wall SM: Angiotensin II acts through the angiotensin 1a receptor to upregulate pendrin. Am J Physiol Renal Physiol 2011;301:F1314-1325.

40 Yang J, Young MJ: The mineralocorticoid receptor and its coregulators. J Mol Endocrinol 2009;43:53-64.

-41 Shigaev A, Asher C, Latter H, Garty H, Reuveny E: Regulation of sgk by aldosterone and its effects on the epithelial $\mathrm{Na}^{+}$channel. Am J Physiol Renal Physiol 2000;278:F613-F619.

$\$ 42$ Caprio M, Feve B, Claes A, Viengchareun S, Lombes M, Zennaro MC: Pivotal role of the mineralocorticoid receptor in corticosteroid-induced adipogenesis. FASEB J 2007;21:2185-2194.

43 Lombes M, Oblin ME, Gasc JM, Baulieu EE, Farman N, Bonvalet JP: Immunohistochemical and biochemical evidence for a cardiovascular mineralocorticoid receptor. Circ Res 1992;71:503-510.

44 Meijer OC: Coregulator proteins and corticosteroid action in the brain. J Neuroendocrinol 2002;14:499-505.

45 Pearce D, Bhargava A, Cole TJ: Aldosterone: its receptor, target genes, and actions. Vitam Horm 2003;66:29-76.

$\checkmark 46$ Lombes M, Farman N, Bonvalet JP, Zennaro MC: Identification and role of aldosterone receptors in the cardiovascular system. Ann Endocrinol (Paris) 2000;61:41-46.

-47 Vallon V, Huang DY, Grahammer F, Wyatt AW, Osswald H, Wulff P, Kuhl D, Lang F: SGK1 as a determinant of kidney function and salt intake in response to mineralocorticoid excess. Am J Physiol Regul Integr Comp Physiol 2005;289:R395-R401.

48 Funder JW: Aldosterone, hypertension and heart failure: insights from clinical trials. Hypertens Res 2010;33:872-875.

49 Latouche C, Sainte-Marie Y, Steenman M, Castro CP, Naray-Fejes-Toth A, Fejes-Toth G, Farman N, Jaisser F: Molecular signature of mineralocorticoid receptor signaling in cardiomyocytes: from cultured cells to mouse heart. Endocrinology 2010;151:4467-4476.

50 Fejes-Toth G, Naray-Fejes-Toth A: Early aldosterone-regulated genes in cardiomyocytes: clues to cardiac remodeling? Endocrinology 2007;148:1502-1510.

51 Fagart J, Huyet J, Pinon GM, Rochel M, Mayer C, Rafestin-Oblin ME: Crystal structure of a mutant mineralocorticoid receptor responsible for hypertension. Nat Struct Mol Biol 2005;12:554-555.

52 Young M, Funder JW: Aldosterone and the heart. Trends Endocrinol Metab 2000;11:224-226.

53 Oberleithner H: Is the vascular endothelium under the control of aldosterone? Facts and hypothesis. Pflugers Arch 2007;454:187-193.

54 Lang F: Stiff endothelial cell syndrome in vascular inflammation and mineralocorticoid excess. Hypertension 2011;57:146-147.

55 Oberleithner H, Kusche-Vihrog K, Schillers H: Endothelial cells as vascular salt sensors. Kidney Int 2010;77:490494.

-56 Sugiyama T, Yoshimoto T, Tsuchiya K, Gochou N, Hirono Y, Tateno T, Fukai N, Shichiri M, Hirata Y: Aldosterone induces angiotensin converting enzyme gene expression via a JAK2-dependent pathway in rat endothelial cells. Endocrinology 2005;146:3900-3906.

57 Lacolley P, Challande P, Osborne-Pellegrin M, Regnault V: Genetics and pathophysiology of arterial stiffness. Cardiovasc Res 2009;81:637-648.

58 Voelkl J, Alesutsn I, Leibrock CB, Quintanilla-Martinez L, Kuhn V, Feger M, Mia S, Ahmed MS, Rosenblatt KP, Lang F: Spironolactone-sensitive vascular calcification and Pit-1-dependent osteoblastic differentiation in klotho-hypomorphic mice. J Clin Invest 2012, in press.

-59 Jaffe IZ, Tintut Y, Newfell BG, Demer LL, Mendelsohn ME: Mineralocorticoid receptor activation promotes vascular cell calcification. Arterioscler Thromb Vasc Biol 2007;27:799-805.

60 de Kloet ER, Joels M, Holsboer F: Stress and the brain: from adaptation to disease. Nat Rev Neurosci 2005;6:463-475.

61 Firsov D: Revisiting sodium and water reabsorption with functional genomics tools. Curr Opin Nephrol Hypertens 2004;13:59-65. 
62 Lacolley P, Challande P, Osborne-Pellegrin M, Regnault V: Genetics and pathophysiology of arterial stiffness. Cardiovasc Res 2009;81:637-648.

63 Latouche C, Sainte-Marie Y, Steenman M, Castro CP, Naray-Fejes-Toth A, Fejes-Toth G, Farman N, Jaisser F: Molecular signature of mineralocorticoid receptor signaling in cardiomyocytes: from cultured cells to mouse heart. Endocrinology 2010;151:4467-4476.

64 Fejes-Toth G, Naray-Fejes-Toth A: Early aldosterone-regulated genes in cardiomyocytes: clues to cardiac remodeling? Endocrinology 2007;148:1502-1510.

65 Kellner M, Peiter A, Hafner M, Feuring M, Christ M, Wehling M, Falkenstein E, Losel R: Early aldosterone upregulated genes: new pathways for renal disease? Kidney Int 2003;64:1199-1207.

66 Sekizawa N, Yoshimoto T, Hayakawa E, Suzuki N, Sugiyama T, Hirata Y: Transcriptome analysis of aldosteroneregulated genes in human vascular endothelial cell lines stably expressing mineralocorticoid receptor. Mol Cell Endocrinol 2011;341:78-88.

67 Hafner P, Grimaldi R, Capuano P, Capasso G, Wagner CA: Pendrin in the mouse kidney is primarily regulated by Cl- excretion but also by systemic metabolic acidosis. Am J Physiol Cell Physiol 2008;295:C1658-C1667.

-68 Lang F, Bohmer C, Palmada M, Seebohm G, Strutz-Seebohm N, Vallon V: (Patho)physiological significance of the serum- and glucocorticoid-inducible kinase isoforms. Physiol Rev 2006;86:1151-1178.

69 Eylenstein A, Schmidt S, Gu S, Yang W, Schmid E, Schmidt EM, Alesutan I, Szteyn K, Regel I, Shumilina E, Lang F: Transcription factor NF-kappaB regulates expression of pore-forming $\mathrm{Ca}^{2+}$ channel unit, Orai1, and its activator, STIM1, to control $\mathrm{Ca}^{2+}$ entry and affect cellular functions. J Biol Chem 2012;287:2719-2730.

-70 Zhu CJ, Wang QQ Zhou JL, Liu HZ, Hua F, Yang HZ, Hu ZW: The mineralocorticoid receptor-p38MAPK-NFkappaB or ERK-Sp1 signal pathways mediate aldosterone-stimulated inflammatory and profibrotic responses in rat vascular smooth muscle cells. Acta Pharmacol Sin 2012;33:873-878.

71 Hoffmann EK, Lambert IH, Pedersen SF: Physiology of cell volume regulation in vertebrates. Physiol Rev 2009;89:193-277.

72 Lang F, Busch GL, Ritter M, Volkl H, Waldegger S, Gulbins E, Haussinger D: Functional significance of cell volume regulatory mechanisms. Physiol Rev 1998;78:247-306.

73 Drumm K, Kress TR, Gassner B, Krug AW, Gekle M: Aldosterone stimulates activity and surface expression of NHE3 in human primary proximal tubule epithelial cells (RPTEC). Cell Physiol Biochem 2006;17:21-28.

74 Krug AW, Papavassiliou F, Hopfer U, Ullrich KJ, Gekle M: Aldosterone stimulates surface expression of NHE3 in renal proximal brush borders. Pflugers Arch 2003;446:492-496.

75 Leite-Dellova DC, Oliveira-Souza M, Malnic G, Mello-Aires M: Genomic and nongenomic dose-dependent biphasic effect of aldosterone on $\mathrm{Na}^{+} / \mathrm{H}^{+}$exchanger in proximal S3 segment: role of cytosolic calcium. Am J Physiol Renal Physiol 2008;295:F1342-F1352.

76 Markos F, Healy V, Harvey BJ: Aldosterone rapidly activates $\mathrm{Na}^{+} / \mathrm{H}^{+}$exchange in $\mathrm{M}-1$ cortical collecting duct cells via a PKC-MAPK pathway. Nephron Physiol 2005;99:1-9.

77 Pinto V, Pinho MJ, Hopfer U, Jose PA, Soares-da-Silva P: Oxidative stress and the genomic regulation of aldosterone-stimulated NHE1 activity in SHR renal proximal tubular cells. Mol Cell Biochem 2008;310:191201.

78 Weigt M, Dietl P, Silbernagl S, Oberleithner $\mathrm{H}$ : Activation of luminal $\mathrm{Na}^{+} / \mathrm{H}^{+}$exchange in distal nephron of frog kidney. An early response to aldosterone. Pflugers Arch 1987;408:609-614.

79 Zhang M, Chen J, Liu S, You L, Lin S, Gu Y: The role of $\mathrm{Na}^{+}-\mathrm{H}^{+}$exchanger isoform 1 in aldosterone-induced glomerulosclerosis in vivo. Ren Fail 2009;31:726-735.

80 Zhang M, Chen J, Lai L, You L, Lin S, Hao C, Gu Y: Aldosterone promotes fibronectin synthesis in rat mesangial cells via ERK1/2-stimulated Na- $\mathrm{H}^{+}$exchanger isoform 1. Am J Nephrol 2010;31:75-82.

-81 Barbato JC, Rashid S, Mulrow PJ, Shapiro JI, Franco-Saenz R: Mechanisms for aldosterone and spironolactoneinduced positive inotropic actions in the rat heart. Hypertension 2004;44:751-757.

-82 De Giusti VC, Nolly MB, Yeves AM, Caldiz CI, Villa-Abrille MC, Chiappe de Cingolani GE, Ennis IL, Cingolani HE, Aiello EA: Aldosterone stimulates the cardiac $\mathrm{Na}^{+} / \mathrm{H}^{+}$exchanger via transactivation of the epidermal growth factor receptor. Hypertension 2011;58:912-919.

83 Karmazyn M, Liu Q Gan XT, Brix BJ, Fliegel L: Aldosterone increases NHE-1 expression and induces NHE-1dependent hypertrophy in neonatal rat ventricular myocytes. Hypertension 2003;42:1171-1176.

-84 Korichneva I, Puceat M, Millanvoye-Van Brussel E, Geraud G, Vassort G: Aldosterone modulates both the Na/H antiport and Cl/HCO3 exchanger in cultured neonatal rat cardiac cells. J Mol Cell Cardiol 1995;27:2521-2528.

85 Young M, Funder J: Mineralocorticoid action and sodium-hydrogen exchange: studies in experimental cardiac fibrosis. Endocrinology 2003;144:3848-3851.

86 Caligiuri A, De Franco RM, Romanelli RG, Gentilini A, Meucci M, Failli P, Mazzetti L, Rombouts K, Geerts A, Vanasia M, Gentilini P, Marra F, Pinzani M: Antifibrogenic effects of canrenone, an antialdosteronic drug, on human hepatic stellate cells. Gastroenterology 2003;124:504-520. 
87 Cho JH, Musch MW, Bookstein CM, McSwine RL, Rabenau K, Chang EB: Aldosterone stimulates intestinal Na ${ }^{+}$ absorption in rats by increasing NHE3 expression of the proximal colon. Am J Physiol 1998;274:C586-C594.

88 Christ M, Douwes K, Eisen C, Bechtner G, Theisen K, Wehling M: Rapid effects of aldosterone on sodium transport in vascular smooth muscle cells. Hypertension 1995;25:117-123.

89 Delva P, Pastori C, Degan M, Montesi G, Bassi A, Lechi A: Erythrocyte $\mathrm{Na}^{+}-\mathrm{H}^{+}$exchanger and $\mathrm{Na}^{+}-$ $\mathrm{Li}^{+}$countertransport activity in primary aldosteronism. Eur J Clin Invest 1994;24:794-798.

-90 Ebata S, Muto S, Okada K, Nemoto J, Amemiya M, Saito T, Asano Y: Aldosterone activates $\mathrm{Na}^{+} / \mathrm{H}^{+}$exchange in vascular smooth muscle cells by nongenomic and genomic mechanisms. Kidney Int 1999;56:1400-1412.

91 Eisen C, Meyer C, Christ M, Theisen K, Wehling M: Novel membrane receptors for aldosterone in human lymphocytes: a 50 kDa protein on SDS-PAGE. Cell Mol Biol (Noisy -le-grand) 1994;40:351-358.

$\$ 92$ Ivanova L, Bernhardt R, Bernhardt I: Nongenomic effect of aldosterone on ion transport pathways of red blood cells. Cell Physiol Biochem 2008;22:269-278.

-93 Koren W, Postnov IY, Postnov YV: Increased $\mathrm{Na}^{+}-\mathrm{H}^{+}$exchange in red blood cells of patients with primary aldosteronism. Hypertension 1997;29:587-591.

$\$ 94$ Koren W, Grienspuhn A, Kuznetsov SR, Berezin M, Rosenthal T, Postnov YV: Enhanced $\mathrm{Na}^{+} / \mathrm{H}^{+}$exchange in Cushing's syndrome reflects functional hypermineralocorticoidism. J Hypertens 1998;16:1187-1191.

-95 Michea L, Delpiano AM, Hitschfeld C, Lobos L, Lavandero S, Marusic ET: Eplerenone blocks nongenomic effects of aldosterone on the $\mathrm{Na}^{+} / \mathrm{H}^{+}$exchanger, intracellular $\mathrm{Ca}^{2+}$ levels, and vasoconstriction in mesenteric resistance vessels. Endocrinology 2005;146:973-980.

-96 Miyata Y, Muto S, Kusano E: Mechanisms for nongenomic and genomic effects of aldosterone on $\mathrm{Na}^{+} / \mathrm{H}^{+}$ exchange in vascular smooth muscle cells. J Hypertens 2005;23:2237-2250.

-97 Musch MW, Lucioni A, Chang EB: Aldosterone regulation of intestinal Na absorption involves SGK-mediated changes in NHE3 and $\mathrm{Na}^{+}$pump activity. Am J Physiol Gastrointest Liver Physiol 2008;295:G909-G919.

$\$ 98$ Oberleithner H, Ludwig T, Riethmuller C, Hillebrand U, Albermann L, Schafer C, Shahin V, Schillers H: Human endothelium: target for aldosterone. Hypertension 2004;43:952-956.

-99 Schiffrin EL: The many targets of aldosterone. Hypertension 2004;43:938-940.

100 Schneider SW, Yano Y, Sumpio BE, Jena BP, Geibel JP, Gekle M, Oberleithner H: Rapid aldosterone-induced cell volume increase of endothelial cells measured by the atomic force microscope. Cell Biol Int 1997;21:759-768.

101 Speake PF, Glazier JD, Greenwood SL, Sibley CP: Aldosterone and cortisol acutely stimulate $\mathrm{Na}^{+} / \mathrm{H}^{+}$exchanger activity in the syncytiotrophoblast of the human placenta: effect of fetal sex. Placenta 2010;31:289-294.

102 Wehling M, Kasmayr J, Theisen K: Fast effects of aldosterone on electrolytes in human lymphocytes are mediated by the sodium-proton-exchanger of the cell membrane. Biochem Biophys Res Commun 1989;164:961-967.

103 Winter DC, Schneider MF, O'Sullivan GC, Harvey BJ, Geibel JP: Rapid effects of aldosterone on sodium-hydrogen exchange in isolated colonic crypts. J Membr Biol 1999;170:17-26.

104 Wagner CA, Finberg KE, Stehberger PA, Lifton RP, Giebisch GH, Aronson PS, Geibel JP: Regulation of the expression of the $\mathrm{Cl} /$ /anion exchanger pendrin in mouse kidney by acid-base status. Kidney Int 2002;62:21092117.

105 Sun X, Soleimani M, Petrovic S: Decreased expression of Slc26a4 (Pendrin) and Slc26a7 in the kidneys of carbonic anhydrase II-deficient mice. Cell Physiol Biochem 2008;21:95-108.

106 Welsh-Bacic D, Nowik M, Kaissling B, Wagner CA: Proliferation of acid-secretory cells in the kidney during adaptive remodelling of the collecting duct. PLoS One 2011;6:e25240.

107 Guder WG, Haussinger D, Gerok W: Renal and hepatic nitrogen metabolism in systemic acid base regulation. J

Clin Chem Clin Biochem 1987;25:457-466. 